\title{
PENGARUH BUKU AJAR IPA TERPADU TEMA KESEHATAN PENCERNAAN DALAM MODEL PEMBELAJARAN KONTEKSTUAL ADAPTIF TERHADAP KOMPETENSI SISWA KELAS VIII SMPN 15 PADANG
}

\author{
Rini Sarimayenti ${ }^{1)}$, Asrizal $^{2)}$, Yulkifli ${ }^{2)}$ \\ ${ }^{1)}$ Mahasiswa Pendidikan Fisika, FMIPA Universitas Negeri Padang \\ ${ }^{2)}$ Staf Pengajar Jurusan Fisika, FMIPA Universitas Negeri Padang \\ rinisarimayenti@gmail.com ${ }^{[1]}$ \\ asrizal_unp@yahoo.com \\ yulkifliamir@gmail.com ${ }^{[2]}$
}

\begin{abstract}
In 2013 curriculum, science teaching should be implemented in integrated form in Junior High School. The real conditions show that integrated science teaching in school can't implemented well. An alternative solution of this problem is to apply the integrated science textbook in adaptive contextual teaching model. The objective of this research was to investigate the effect of integrated science textbook on our digestive health theme in adaptive contextual teaching model toward the competences of the grade VIII students in SMPN 15 Padang. The type of research was quasi experimental research with one group pretest-posttest design. Samples in this research were taken by using the purposive sampling technique. The research instruments consist of observation sheet for attitude competency, written test for knowledge competency and performance assessment for skill competency. Data of this research were analyzed by using descriptive statistical analysis and compare mean test for attitude, knowledge, and skill competences. The results of data analysis show that the implementation of integrated science textbook on our digestive health theme in adaptive contextual teaching model gives significant effect on the attitude, the knowledge and the skill competences at $95 \%$ level confidence of grade VIII students in VIII SMPN 15 Padang.
\end{abstract}

Keywords : Textbook, Integrated Science, Contextual Teaching, Teaching Model.

\section{PENDAHULUAN}

Abad ke-21 merupakan suatu abad yang me miliki persaingan yang ketat dari berbagai bidang. Persaingan itu tidak terlepas dari semua unsur kebutuhan manusia yang selalu berkembang setiap waktu. Dalam abad ke-21 ini diperlukan sumber daya manusia yang siap dan sigap dalam menghadapi per saingan tersebut supaya dapat bertahan dan berkom petensi secara sehat.

Pada abad ke-21, ilmu pengetahuan dan tekno logi berkembang dengan cepat dan pesat. Perkem bangan teknologi terasa semakin cepat karena dipicu oleh adanya kemudahan pada penyebarluasan infor masi melalui berbagai media. Hal ini menyebabkan kehidupan masyarakat ikut berkembang. Dengan alasan ini dibutuhkan pembelajaran kontekstual. Pembelajaran kontekstual yaitu pembelajaran yang menghubungkan materi pengetahuan dengan kehidu pan nyata serta dapat diaplikasikan dalam kehidupan sehari-hari. Pembelajaran konstekstual merupakan suatu sistem pembelajaran yang menghasilkan makna dengan menghubungkan muatan akademis dengan konteks kehidupan sehari-hari siswa ${ }^{[1]}$. Pembelajaran kontekstual akan membantu guru-guru di sekolah untuk mengaitkan materi pembelajaran dengan situa si dunia nyata siswa dan dapat mendorong siswa membuat hubungan antara pengetahuan yang dimiliki nya dengan penerapannya dalam kehidupan nyata siswa sebagai anggota ke luarga dan masyarakat.
Dalam menghadapi tantangan abad ke-21 pe merintah telah melakukan perubahan kurikulum. $\mathrm{Ku}$ rikulum yang diterapkan adalah kurikulum 2013, yang merupakan penyempurnaan dari kurikulum tingkat satuan pendidikan (KTSP). Perubahan men dasar dari kurikulum 2013 dengan kurikulum KTSP adalah desain pembelajarannya, yaitu proses pem belajaran pada kurikulum 2013 dilaksanakan meng gunakan pendekatan saintifik dan mencakup tiga aspek kompetensi yaitu kompetensi sikap, penge tahuan, dan keterampilan. Kurikulum 2013 memiliki tujuan untuk mempersiapkan manusia sehingga da pat memiliki kemampuan hidup sebagai pribadi dan warga negara yang beriman, produktif, kreatif, ino vatif, dan afektif serta mampu berkontribusi pada kehidupan bermasyarakat, berbangsa, bernegara, dan peradaban dunia.

Pendidikan IPA memiliki tujuan untuk mem persiapkan siswa untuk memiliki pemahaman tentang IPA dan teknologi melalui pengembangan sikap, pengetahuan, dan keterampilan sehingga siswa dapat memahami dan memecahkan permasalahan lingku ngan yang ada dikehidupan nyata. Pemahaman ten tang pentingnya mempelajari alam sangat penting da lam kehidupan manusia agar lebih bermakna dan ber martabat. Ditinjau dari fisiknya IPA merupakan ilmu pengetahuan yang menelaah alam dengan segala isi nya yaitu manusia, hewan, dan tumbuhan termasuk bumi $^{[2]}$. Pendidikan IPA dapat mengembangkan 
kemampuan berpikir kritis, logis, sistematis se hingga mampu membekali siswa agar mampu meng hadapi berbagai tantangan dalam masyarakat yang semakin kompetitif.

Kegiatan pembelajaran IPA di SMP memuat metode ilmiah. Metode ilmiah ini mencakup be berapa aspek yaitu: mengamati, menanya, merumus kan masalah, merumuskan hipotesis, merancang percobaan, mengumpulkan data, menganalisis, me nyimpulkan dan memberikan rekomendasi, dan meng komunikasikan hasil. Dari setiap langkah kegiatan IPA sudah terintegrasi didalamnya kegiatan pembe lajaran dengan pendekatan saintifik. Tujuan pembe lajaran IPA terpadu adalah: meningkatkan efisiensi dan efektivitas pembelajaran, meningkatkan minat dan motivasi, sehingga beberapa kompetensi dasar akan dicapai sekaligus ${ }^{[3]}$.

Kurikulum 2013 menuntut agar semua aspek kompetensi dapat dinilai selama proses pembelajaran berlangsung baik pada kompetensi sikap, penge tahuan dan keterampilan. Kompetensi merupakan sesuatu yang dimiliki oleh siswa dan komponen utama yang harus dirumuskan dalam pembelajaran yang memiliki peranan penting dalam menentukan arah pembelajaran ${ }^{[4]}$. Menurut kurikulum 2013 kompetensi siswa mencakup tiga aspek yaitu kompetensi sikap, pengetahuan, dan keterampilan. Kompetensi sikap meliputi sikap, kepribadian, religius dan sosial siswa. Kompetensi pengetahuan meliputi tingkatan kemampuan mengingat, mema hami, menerapkan, menganalisis, mengevaluasi, dan menciptakan. Kompetensi keterampilan meliputi ke cakapan, kerja keras dan aktivitas siswa. Jadi, kom petensi siswa akan tercapai dengan baik jika semua hasil belajar tercapai.

Pencapaian kompetensi harus dilandasi dengan substansi mata pelajaran yang terpadu. Pada hakikat nya mata pelajaran IPA dalam kurikulum 2013 dikembangkan sebagai mata pelajaran dalam bentuk IPA terpadu. Muatan IPA berasal dari ilmu biologi, fisika, dan kimia. Dengan kata lain, IPA sebagai salah satu mata pelajaran hendaknya diajarkan secara terpadu, tidak dipisah-pisahkan antara materi Biologi, Fisika, dan Kimia. Keterpaduan dalam pembelajaran IPA dilakukan agar pembelajaran yang dilaksanakan lebih bermakna, mampu menumbuhkan kreativitas siswa dan lebih menyenangkan sehingga sesuai dengan tuntutan kurikulum 2013 ${ }^{[5]}$. Model pembe lajaran terpadu terdiri atas beberapa macam, yaitu: model terhubung, model tergambarkan, model ter sarang, model terurut, model terbagi, model terjaring, model tertali, model terpadu, model terbenam, dan model jaringan ${ }^{[6]}$.

Dari pelaksanaan pembelajaran IPA terpadu banyak manfaat yang dapat diambil. Manfaat pembe lajaran IPA terpadu antara lain: menghemat waktu, meningkatkan taraf kecakapan berpikir siswa, me nyajikan penerapan atau aplikasi tentang dunia nyata yang dialami dalam kehidupan sehari-hari, memper baiki dan meningkatkan motivasi belajar siswa, mem bantu menciptakan struktur kognitif yang dapat men jembatani antara pengetahuan awal siswa dengan pengalaman belajar yang terkait, sehingga lebih ter organisisasi dan mendalam, dan memudahkan me mahami hubungan materi IPA dari satu konteks ke konteks lainnya ${ }^{[7]}$. Penerapan materi pembelajaran IPA secara terpadu dapat meningkatkan kompetensi pengetahuan siswa, meningkatkan kompetensi sikap siswa dan meningkatkan kompetensi keterampilan literasi siswa ${ }^{[8]}$.

Untuk meningkatkan kualitas aspek suatu pembelajaran tidak terlepas dari bahan ajar. Bahan ajar merupakan segala bentuk bahan yang digunakan untuk membantu guru dalam melaksanakan kegiatan pembelajaran $^{[3]}$. Sebuah bahan ajar paling tidak men cakup beberapa hal sebagai berikut: petunjuk belajar, kompetensi yang akan dicapai, isi materi pembelaja ran, informasi pendukung, latihan-latihan, petunjuk kerja, evaluasi, dan balikan terhadap hasil evaluasi. Disisi lain ada beberapa aspek yang perlu diperhati kan dalam penyusunan bahan ajar adalah evaluasi terhadap bahan ajar. Evaluasi ini dimaksudkan untuk mengetahui kekuatan dan kelemahan dari bahan ajar sehingga dapat dilakukan revisi ${ }^{[9]}$. Peranan dari bahan ajar tidak hanya dibatasi untuk pengetahuan siswa saja, tetapi melalui bahan ajar diciptakan usaha peningkatan nilai-nilai yang terkandung dalam pem belajaran pendidikan.

Bahan ajar memiliki fungsi dalam kegiatan pembelajaran baik untuk guru maupun siswa. Fungsi bahan ajar bagi guru yaitu untuk menghemat waktu, menciptakan pembelajaran yang efektif dan interak tif, serta sebagai alat evaluasi pembelajaran. Disisi lain, fungsi bahan ajar bagi siswa adalah sebagai pe doman pencapaian kompetensi. Pembelajaran IPA terpadu pada dasarnya memerlukan bahan ajar yang lebih lengkap dan komprehensif.

Kenyataan di lapangan, pembelajaran IPA terpadu belum sesuai dengan yang diharapkan. Hal ini dapat diketahui melalui studi pendahuluan yang telah dilakukan oleh peneliti untuk menganalisis masalah penelitian. Ada tiga studi pendahuluan yang dilakukan yaitu pelaksanaan pembelajaran IPA, analisis buku ajar dan analisis hasil belajar siswa.

Kenyataan pertama didapatkan dari hasil wawancara dengan dua orang guru IPA SMPN 15 Padang. Hasil wawancara yang diperoleh, yaitu: pembelajaran IPA terpadu belum berjalan dengan baik, model pembalajaran yang sesuai dengan kuri kulum 2013 sudah mulai diterapkan akan tetapi masih belum berjalan dengan baik, dan guru belum melaksanakan pembelajaran kontekstual dengan baik. Kenyataan kedua didapatkan dari hasil analisis lima buku ajar IPA terpadu. Berdasarkan analisis didapat kan nilai keterpaduan sebesar 43,67. Keterpaduan dari buku ajar ini masih tergolong rendah. Kenyataan ketiga adalah hasil belajar siswa belum memenuhi harapan. Hal ini dapat terlihat dari hasil belajar siswa 
SMPN 15 Padang pada ujian semester genap mata pelajaran IPA. Nilai rata-rata ujian semester IPA paling rendah adalah 38,97 dan paling tinggi adalah 68,84 . Nilai rata-rata ujian semester IPA untuk semua siswa kelas VIII SMP Negeri 15 Padang tahun ajaran 2016/2017 adalah 47,34.

Berdasarkan kondisi yang diharapkan dengan kondisi nyata di lapangan ditemukan adanya kesenja ngan. Pada kenyataannya pelaksanaan IPA terpadu belum diterapkan dengan baik, penggunaan model pembelajaran sesuai kurikulum 2013 belum terlak sana dengan baik, buku ajar yang digunakan belum terpadu secara keseluruhannya, dan hasil belajar siswa yang belum memenuhi harapan. Dalam pe laksanaan pembelajaran IPA di sekolah seharusnya juga sejalan dengan penggunaan buku ajar yang juga terpadu. Salah satu media pembelajaran berbasis cetakan adalah buku ajar. Buku ajar merupakan buku yang digunakan dalam pembelajaran pada bidang studi tertentu. Sebuah buku ajar disusun oleh pakarpakar dalam bidangnya masing-masing untuk mak sud dan tujuan instruksional, yang dilengkapi dengan sarana pembelajaran yang serasi dan mudah di pahami oleh para pemakainya di sekolah-sekolah dan perguruan tinggi sehingga dapat menunjang suatu progam pembelajaran ${ }^{[10]}$. Buku ajar juga merupakan sarana penunjang kegiatan belajar mengajar yang berisi materi dengan bidang studi atau mata pelajaran tertentu, yang disusun secara sistematis dan ber orientasi kepada siswa $^{[11]}$.

Salah satu solusi untuk mengatasi masalah dalam penelitian ini adalah menggunakan buku ajar IPA terpadu tema kesehatan pencernaan dalam model pembelajaran kontekstual adaptif. Buku ajar IPA terpadu yang digunakan pada penelitian ini meru pakan sebuah produk penelitian yang dibuat oleh Asrizal $(2017)^{[12]}$. Buku ajar IPA terpadu ini telah di validasi oleh 5 orang tenaga ahli dengan nilai validi tas produk 88,5. Setelah dilakukan analisis data terha dap hasil uji praktikalitas yang dilakukan oleh tiga orang guru dan siswa terhadap buku ajar IPA terpadu diperoleh masing-masing nilai sebesar 86,11 dan 86,66 . Buku ajar ini berisikan materi IPA secara ter padu dalam satu kesatuan yang utuh dan juga me nyeluruh. Materi pembelajaran dalam buku ajar ini dikemas secara kontekstual, sehingga dapat mengop timalkan penilaian terhadap kompetensi sikap, penge tahuan, dan juga keterampilan siswa.

Pada penerapan buku ajar IPA terpadu ini pembelajaran dilakukan dengan model pembelajaran kontekstual adaptif. Model pembelajaran kontekstual adaptif adalah kerangka konseptual yang melukiskan prosedur yang sistematis dalam mengorganisasikan pengalaman belajar untuk mencapai tujuan belajar tertentu, dan berfungsi sebagai pedoman bagi guru dalam merencanakan dan melaksanakan kegiatan pembelajaran yang mampu menghubungkan materi pembelajaran dengan situasi dunia nyata siswa. Tuju an dari model pembelajaran kontekstual adaptif ada lah membantu guru untuk menghubungkan materi pembelajaran dengan situasi dunia nyata siswa serta membantu guru untuk membuat pembelajaran ber makna bagi siswa ${ }^{[14]}$.

Beberapa penelitian yang relevan dengan penelitian ini adalah Asrizal ${ }^{[9]}$ Junaydi ${ }^{[10]}$, dan Septian ${ }^{[15]}$. Setidaknya ada tiga perbedaan penelitian ini dengan penelitian sebelumnya. Pertama, buku ajar IPA terpadu yang digunakan pada penelitian ini mengintegrasikan strategi kontekstual. Kedua, buku ajar IPA terpadu memiliki keterpaduan antar materi. Ketiga, model pembelajaran yang digunakan adalah model pembelajaran kontekstual adaptif.

Tujuan penelitian ini adalah untuk menyelidiki pengaruh buku ajar IPA terpadu tema kesehatan pencernaan dalam model pembelajaran kontekstual adaptif terhadap kompetensi siswa kelas VIII SMPN 15 Padang. Disisi lain sebagai hipotesis kerja pada penelitian ini yaitu "terdapat pengaruh yang berarti pada penggunaan buku ajar IPA terpadu tema ke sehatan pencernaan dalam model pembelajaran kon tekstual adaptif terhadap kompetensi siswa kelas VIII SMPN 15 Padang".

\section{METODE PENELITIAN}

Jenis penelitian yang akan dilakukan sesuai dengan permasalahan dan tujuan yang ingin dicapai yaitu menggunakan eksperimen semu. Dalam pene litian ini digunakan desain tes awal-tes akhir satu kelompok. Penelitian ini membutuhkan satu kelas yaitu kelas eksperimen dimana dalam pembelajaran nya menggunakan buku ajar IPA terpadu tema ke sehatan pencernaan. Pada penelitian ini dibutuhkan tes awal siswa sebelum diberikan perlakuan dan hasil tes akhir setelah diberikan perlakuan. Jenis penelitian yang digunakan dapat dinyatakan pada Tabel 1 .

Tabel 1. Desain Tes Awal-Tes Akhir Satu Kelompok

\begin{tabular}{|c|c|c|}
\hline Tes Awal & Perlakuan & Tes Akhir \\
\hline $\mathrm{O}_{1}$ & $\mathrm{X}$ & $\mathrm{O}_{2}$ \\
\hline
\end{tabular}

Keterangan:

$\mathrm{O}_{1}=$ Tes awal yang dilakukan pada kelas eks perimen

$\mathrm{X}=$ Perlakuan yang diberikan pada kelas eks perimen yaitu pembelajaran menggunakan buku ajar IPA terpadu tema kesehatan pen cernaan dalam model pembelajaran konteks tual adaptif.

$\mathrm{O}_{2}=$ Tes akhir yang dilakukan pada kelas eks perimen.

Penelitian ini memiliki dua variabel penelitian yaitu variabel bebas dan variabel terikat. Variabel bebas dalam penelitian ini adalah buku ajar IPA terpadu tema kesehatan pencernaan dalam model pembelajaran kontekstual adaptif. Variabel terikat pada penelitian ini adalah kompetensi siswa kelas VIII SMPN 15 Padang.

Populasi dari penelitian ini meliputi seluruh siswa kelas VIII SMPN 15 Padang yang terdaftar pada semester 1 tahun ajaran 2017/2018. Teknik pe 
ngambilan sampel pada penelitian ini menggunakan teknik sampel bertujuan. Pengambilan sampel pada teknik ini dilakukan dengan cara mengambil subjek bukan didasarkan atas strata atau random, tetapi di dasarkan atas tujuan tertentu. Pada penelitian ini sam pel berjumlah satu kelas. Sampel pada penelitian ini adalah kelas VIII.7.

Prosedur pada penelitian ini meliputi tiga tahap. Tiga tahap tersebut adalah tahap perencanaan, tahap pelaksanaan, dan tahap penyelesaian. Masingmasing tahap juga memiliki beberapa langkah-lang kah yang harus dipenuhi.

Data yang diambil untuk penelitian ini ada beberapa macam, seperti nilai observasi sikap untuk kompetensi sikap, nilai tes awal dan nilai tes akhir serta nilai-nilai tugas siswa yang terdapat dalam buku ajar IPA terpadu tema kesehatan pencernaan pada kompetensi pengetahuan, dan nilai unjuk kerja untuk kompetensi keterampilan. Teknik pengumpu lan data pada kompetensi sikap digunakan teknik observasi dan instrumen yang digunakan pada kompe tensi sikap adalah lembar observasi, pada kompetensi pengetahuan menggunakan teknik tes tulis dengan instrumen penilaian yaitu pilihan ganda dan essai, dan pada kompetensi keterampilan dinilai selama pro ses eksperimen berlangsung menggunakan teknik skala penilaian.

Instrumen penelitian disesuaikan dengan varia bel penelitian, data yang akan diambil dan statistik penguji dalam penelitian. Instrumen yang digunakan dalam penelitian ini adalah sebagai berikut: untuk aspek sikap menggunakan lembar observasi yang dikembangkan sesuai dengan penilaian aspek-aspek yang dibutuhkan saat pembelajaran berlangsung, pada aspek pengetahuan menggunakan tes tulis ber bentuk pilihan ganda yang mengacu pada indikator pencapaian kompetensi, dan pada aspek keterampi lan digunakan skala penilaian.

Analisis data yang digunakan adalah analisis uji statistik deskriprif dan analisis uji hipotesis untuk semua kompetensi. Pada statistik deskriptif, akan me nyajikan data melalui tabel, grafik, diagram lingka ran, pictogram, perhitungan mean, media, modus, dan variasi kelompok melalui rentang dan simpangan baku. Hasil analisis bertujuan untuk mengetahui pengaruh yang berarti pada penggunaan buku ajar IPA terpadu. Untuk itu digunakan statistik deskriptif, uji analisis regresi linear sederhana, uji hubungan dua variabel, uji hipotesis.

Analisis regresi dilakukan untuk mengetahui seberapa kuat hubungan antara dua variabel. Bentuk umum dari regresi linear sederhana adalah $\mathrm{Y}$ dan $\mathrm{X}$ yang ditaksirkan oleh persamaan:

$$
\hat{Y}=a+b X
$$

Keterangan:

$\mathrm{Y}=$ Variabel dependen yang diprediksikan.

$\mathrm{a}=$ Harga $\mathrm{Y}$ ketika harga $\mathrm{X}=0$

$\mathrm{b}=$ Angka arah atau koefisien regresi, yang me nunjukkan angka peningkatan ataupun penuru nan variabel dependen yang didasarkan pada perubahan variabel independen.

$\mathrm{X}=$ Variabel independen yang mempunyai nilai tertentu.

Jika variabel yang dihubungkan tersebut termasuk data interval, dan sebaran datanya terdistri busi normal, maka digunakan rumus uji hubungan dua variabel berikut:

$$
r=\frac{n\left(\sum X_{i} Y_{i}\right)-\left(\sum X_{i}\right)\left(\sum Y_{i}\right)}{\sqrt{\left(n \sum X_{i}^{2}-\left(\sum X_{i}\right)^{2}\right)\left(n \sum Y_{i}^{2}-\left(\sum Y_{i}\right)^{2}\right.}}
$$

Statistik yang digunakan untuk menguji hipotesis komparatif rata-rata dua sampel jika datanya berbentuk interval atau ratio adalah menggunakan t-test. Rumusan t-test yang digunakan sebagai uji hipotesis komparatif dua sampel yang berkorelasi ditunjukan pada rumus :

$$
t=\frac{\overline{X_{1}}-\overline{X_{2}}}{\sqrt{\frac{s_{1}^{2}}{n_{1}}+\frac{s_{2}^{2}}{n_{2}}-2 r\left(\frac{s_{1}}{\sqrt{n_{1}}}\right)\left(\frac{s_{2}}{\sqrt{n_{2}}}\right)}} .
$$

Dimana :

$\overline{X_{1}}=$ Rata-rata sampel 1

$\overline{\boldsymbol{X}_{2}}=$ Rata-rata sampel 2

$\mathrm{S}_{1} \quad=$ Simpangan baku sampel 1

$\mathrm{S}_{2} \quad=$ Simpangan baku sampel 2

$\mathrm{S}_{1}^{2}=$ Varians sampel 1

$\mathrm{S}_{2}^{2}=$ Varians sampel 2

$\mathrm{r} \quad=$ Hubungan dua variabel

Koefisisen korelasi menunjukkan derajat keeratan hubungan variabel $\mathrm{X}$ dan $\mathrm{Y}$. Untuk menguji keberatian hubungan variabel $\mathrm{X}$ dengan $\mathrm{Y}$ maka di lakukan Uji t. Pada penelitian ini uji t dilakukan untuk mengetahui keberartian hubungan antara kom petensi pengetahuan siswa dengan nilai tugas-tugas pengetahuan yang terdapat dalam buku ajar IPA terpadu tema kesehatan pencernaan. maka dilakukan uji signifikan dengan rumus :

$$
\mathrm{t}=\frac{r \sqrt{n-2}}{\sqrt{1-r^{2}}}
$$

Keterangan:

$r \quad=$ Hubungan dua variabel

$\mathrm{n}=$ Jumlah sampel

\section{HASIL PENELITIAN DAN PEMBAHASAN}

\section{Hasil Penelitian}

Hasil penelitian pertama adalah pengaruh buku ajar IPA terpadu tema kesehatan pencernaan dalam model pembelajaran kontekstual adaptif terhadap kompetensi sikap siswa. Data kompetensi sikap siswa diperoleh selama kegiatan pembelajaran berlangsung. Data ini diambil dari nilai sikap awal siswa sebelum menggunakan buku ajar IPA terpadu dan selama kegiatan pembelajaran menggunakan buku ajar IPA terpadu. Penilaian sikap menggunakan lembar observasi dan dibantu oleh observer. Penilai an kompetensi sikap menggunakan lembar observasi dilakukan terhadap enam aspek penilaian yaitu sikap ingin tahu, percaya diri, disiplin, komitmen inkuiri, 
kerja sama, dan komunikatif. Deskripsi data sikap ini ditunjukkan oleh skor total yang diperoleh siswa untuk tiap indikator sikap yang dilakukan siswa selama dua belas kali pertemuan tatap tatap muka di kelas. Nilai rata-rata sikap untuk masing-masing indikator dapat dinyatakan dalam bentuk grafik seperti pada Gambar 1

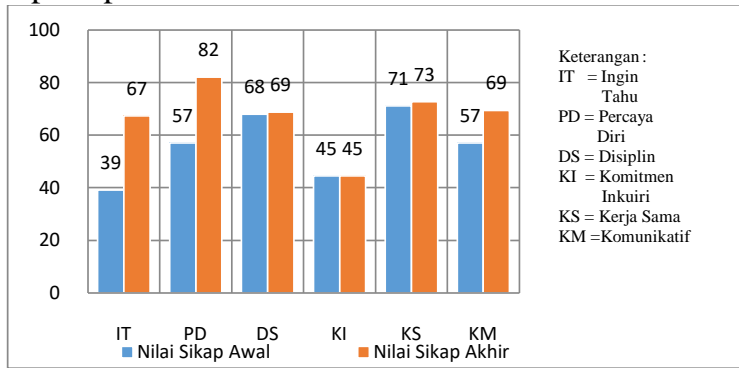

Gambar 1. Nilai Rata-Rata Sikap Pada MasingMasing Indikator

Berdasarkan Gambar 1 dapat dideskripsikan bahwa pada indikator sikap ingin tahu, percaya diri, disiplin, kerja sama dan komunikatif nilai sikap akhir siswa mengalami peningkatan sedangkan untuk indi kator komitmen inkuiri sikap awal dan sikap akhir siswa. Setelah didapatkan nilai sikap siswa pada ma sing-masing indikator lalu dihitung rata-rata nilai si kap awal dan sikap akhir siswa. Deskripsi data kom petensi sikap awal dan sikap akhir dapat dinyatakan pada Tabel 2.

Tabel 2. Deskripsi Data Kompetensi Sikap Awal dan sikap Akhir

\begin{tabular}{|l|c|c|c|c|c|c|}
\hline Keadaan & N & $\begin{array}{c}\text { Nilai } \\
\text { Terting } \\
\text { gi }\end{array}$ & $\begin{array}{c}\text { Nilai } \\
\text { Teren } \\
\text { dah }\end{array}$ & $\bar{X}$ & $\mathrm{~S}^{2}$ & S \\
\hline Sikap Awal & 32 & 77,08 & 43,75 & 56,12 & 67,40 & 8,21 \\
\hline Sikap Akhir & 32 & 89,58 & 54,17 & 67,45 & 75,46 & 8,69 \\
\hline
\end{tabular}

Pada Tabel 2 dapat dijelaskan bahwa nilai rata-rata sikap awal lebih rendah dari nilai rata-rata sikap akhir siswa. Langkah pertama untuk melakukan uji hipotesis adalah dengan cara melihat apakah data kompetensi sikap terdistribusi normal atau tidak de ngan menggunakan uji lilifors. Hasil uji normalitas di dapatkan harga $L_{o}$ dan $L_{t}$ pada taraf nyata 0,05 seperti terlihat pada Tabel 3 .

Tabel 3. Hasil Uji Normalitas Sikap Awal dan Sikap Akhir Siswa

\begin{tabular}{|c|c|c|c|c|c|}
\hline Penilaian & $\mathbf{N}$ & $\alpha$ & Lo & Lt & Keterangan \\
\hline Sikap Awal & 32 & 0,05 & 0,126 & 0,156 & Normal \\
\hline Sikap Akhir & 32 & 0,05 & 0,098 & 0,156 & Normal \\
\hline
\end{tabular}

Setelah data terdistribusi normal peneliti mela kukan uji hubungan dua variabel. Dari hasil analisis diperoleh nilai hubungan (r) sebesar 0,99. Setelah diperoleh nilai hubungan tersebut kemudian peneliti melakukan uji hipotesis.

Dari hasil uji hipotesis diperoleh nilai $t_{h}$ ada lah -10,80. Harga $t_{t}$ dengan dk 62 dan jika taraf kesalahan ditetapkan sebesar 5\% maka nilai $\mathrm{t}_{\mathrm{t}}=2,00$. Karena $t_{\mathrm{h}}$ berharga negatif maka digunakan uji pihak kiri dan harga $t_{t}=-2,00$. Nilai $t_{h}$ pada penelitian lebih kecil dari pada t. Dari hasil tersebut dapat dinyatakan bahwa penggunaan buku ajar IPA terpadu tema kesehatan pencernaan dalam model pembelajaran kontekstual adaptif memberikan pengaruh yang berarti terhadap kompetensi sikap siswa kelas VIII SMPN 15 Padang.

Hasil penelitian kedua adalah pengaruh buku ajar IPA terpadu tema kesehatan pencernaan dalam model pembelajaran kontekstual adaptif terhadap kompetensi pengetahuan siswa. Data kompetensi pengetahuan IPA siswa diperoleh dari hasil tes tulis diawal pembelajaran berupa tes awal berbentuk soal objektif sebanyak 25 soal, tes akhir berbentuk soal ob jekif sebanyak 40 soal, dan nilai tugas-tugas penge tahuan dalam buku ajar. Nilai tes awal dihubungkan dengan nilai tes akhir untuk melihat pengaruh buku ajar IPA terpadu. Deskripsi data hasil penelitian un tuk nilai tes awal dan nilai tes akhir dapat dinyatakan pada Tabel 4.

Tabel 4. Deskripsi Data Kompetensi Pengetahuan Tes Awal dan Tes Akhir

\begin{tabular}{|c|c|c|c|c|c|c|}
\hline Keadaan & $\mathrm{N}$ & $\begin{array}{c}\text { Nilai } \\
\text { Tertinggi }\end{array}$ & $\begin{array}{c}\text { Nilai } \\
\text { Terendah }\end{array}$ & $\bar{X}$ & $\mathrm{~S}^{2}$ & $\mathrm{~S}$ \\
\hline Tes Awal & 32 & 68 & 36 & 48,25 & 45,35 & 6,73 \\
\hline Tes Akhir & 32 & 80 & 42,5 & 56,79 & 87,59 & 9,36 \\
\hline
\end{tabular}

Syarat melakukan uji hipotesis adalah data harus terdistribusi normal. Uji normalitas yang di lakukan adalah uji Lilliefors. Hasil uji normalitas didapatkan harga $\mathrm{L}_{\mathrm{o}}$ dan $\mathrm{L}_{\mathrm{t}}$ pada taraf nyata 0,05 seperti terlihat pada Tabel 5 .

Tabel 5. Hasil Uji Normalitas Tes Awal dan Tes Akhir Siswa

\begin{tabular}{|l|c|c|c|c|c|}
\hline \multicolumn{1}{|c|}{ Penilaian } & $\mathbf{N}$ & $\alpha$ & Lo & Lt & Keterangan \\
\hline Tes Awal & 32 & 0.05 & 0.133 & 0.156 & Normal \\
\hline Tes Akhir & 32 & 0.05 & 0.138 & 0.156 & Normal \\
\hline
\end{tabular}

Setelah data terdistribusi normal dilakukan uji normalitas kemudian dilakukan uji hubungan dua variabel untuk mengetahui besar pengaruh buku ajar IPA terpadu pada kompetensi pengetahuan. Dari hasil analisis diperoleh nilai korelasi sebesar 0,52. Nilai korelasi ini kemudian digunakan untuk menguji hipotesis. Uji hipotesis dilakukan untuk mengetahui pengaruh yang berarti pada penggunaan buku ajar IPA terpadu tema kesehatan pencernaan dalam model kontekstual adaptif terhadap kompetensi pengetahuan siswa kelas VIII SMPN 15 Padang.

Hasil uji hipotesis kompetensi pengetahuan diperoleh nilai $t_{h}$ sebesar $-4,05$ dan $t_{t}$ adalah $-2,00$. Nilai $t_{h}$ yang didapatkan pada penelitian lebih kecil dari pada bnilai $t_{t}$. Hasil analisis uji hipotesis menunjukkan bahwa pada penggunaan buku ajar IPA terpadu tema kesehatan pencernaan dalam model pembe lajaran kontekstual adaptif memberikan pengaruh yang berarti terhadap kompetensi pengetahuan siswa kelas VIII SMPN 15 Padang.

Untuk melihat hubungan antara kompetensi pengetahuan dengan nilai tugas dalam buku ajar 
dilakukan uji korelasi. Nilai tes akhir dihubungkan dengan nilai tugas-tugas dalam buku ajar IPA terpadu untuk melihat seberapa besar pengaruh penerapan buku tersebut terhadap nilai kompetensi pengetahuan siswa. Deskripsi data hasil penelitian pada tugastugas buku ajar IPA terpadu dengan tes akhir dapat di nyatakan pada Tabel 6.

Tabel 6. Deskripsi Data Kompetensi Pengetahuan IPA Siswa pada Tugas-Tugas Buku Ajar IPA Terpadu dan Tes Akhir

\begin{tabular}{|l|c|c|c|c|c|c|}
\hline \multicolumn{1}{|c|}{ Keadaan } & $\mathrm{N}$ & $\begin{array}{c}\text { Nilai } \\
\text { Tertinggi }\end{array}$ & $\begin{array}{c}\text { Nilai } \\
\text { Terendah }\end{array}$ & $\bar{X}$ & $\mathbf{S}^{\mathbf{2}}$ & $\mathrm{S}$ \\
\hline $\begin{array}{l}\text { Tugas } \\
\text { Pengetahuan }\end{array}$ & 32 & 96 & 57 & 82,38 & 105,99 & 10,29 \\
\hline Tes Akhir & 32 & 80 & 42,5 & 56,79 & 87,59 & 9,36 \\
\hline
\end{tabular}

Dari hasil perhitungan statistik dapat dinyata kan bahwa terdapat perbedaan kompetensi penge tahuan IPA siswa antara nilai tugas pengetahuan da lam buku ajar IPA terpadu dan tes akhir. Rata-rata nilai tugas-tugas dalam buku ajar IPA terpadu lebih tinggi di bandingkan dengan rata-rata hasil tes akhir.

Sebelum melakukan uji hipotesis pada kom petensi pengetahuan terlebih dahulu dilakukan uji nor malitas. Uji normalitas dilakukan untuk mengetahui apakah data kompetensi pengetahuan terdistribusi normal atau tidak. Uji normalitas yang digunakan adalah uji Lilliefors. Hasil uji normalitas didapatkan harga $\mathrm{L}_{\mathrm{o}}$ dan $\mathrm{L}_{\mathrm{t}}$ pada taraf nyata 0,05 dapat dinyata kan pada Tabel 7.

Tabel 7. Hasil Uji Normalitas Kompetensi Penge tahuan pada Tugas-Tugas Pengetahuan da lam Buku Ajar dan Tes Akhir

\begin{tabular}{|l|c|c|c|c|c|}
\hline \multicolumn{1}{|c|}{ Penilaian } & $\mathbf{N}$ & $\boldsymbol{\alpha}$ & $\mathbf{L o}$ & $\mathbf{L t}$ & Keterangan \\
\hline $\begin{array}{l}\text { Tugas } \\
\text { Pengetahuan }\end{array}$ & 32 & 0,05 & 0,09 & 0,156 & Normal \\
\hline Tes Akhir & 32 & 0,05 & 0,138 & 0,156 & Normal \\
\hline
\end{tabular}

Setelah dilakukan uji normalitas didapatkan bahwa data nilai tugas pengetahuan dalam buku ajar dan nilai tes akhir terdistribusi normal. Setelah data terditribusi normal dilakukan uji regresi linear seder hana untuk melihat hubungan regresi linear data ini berarti atau tidak. Hubungan antara kompetensi pe ngetahuan dengan nilai tugas dalam buku ajar dapat dinyatakan dalam bentuk grafik pada Gambar 2

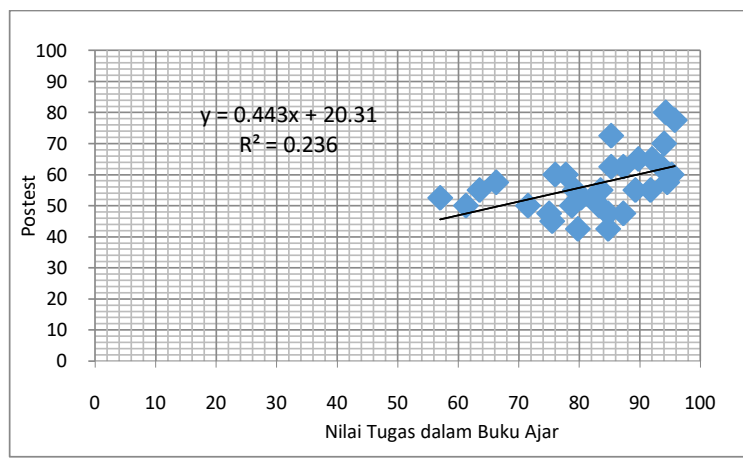

Gambar 2. Hubungan Kompetensi Pengetahuan dengan Buku Ajar IPA terpadu
Dari Gambar 2 dapat dijelaskan bahwa data pada kompetensi pengetahuan terdistribusi linear. Da ta tersebar disekitar garis lurus. Uji regresi linear se derhana dinyatakan dalam persamaan regresi linear sederhana, yaitu:

$$
\widehat{Y}=2,24+0,44 X
$$

Uji keberatian dan uji linearitas dapat ditentu kan menggunakan Tabel 8.

Tabel 8. Analisis Varians Regresi Linear Sederhana

\begin{tabular}{|c|c|c|c|c|}
\hline Sumber Varian & $\mathrm{Dk}$ & JK & KT & $\mathrm{F}$ \\
\hline Total & 32 & 105943,75 & 105943,75 & \\
\hline Koefisien (a) & 1 & 103228,3125 & 103228,3125 & \\
\hline Regresi (b/a) & 1 & 640,1156 & 640,1156 & \multirow{2}{*}{$\begin{array}{c}\mathrm{Fh}=9,25 \\
\mathrm{Ft}=4,17 \\
\mathrm{Fh}>\mathrm{Ft}\end{array}$} \\
\hline Sisa & 30 & 2075,3219 & 69,1774 & \\
\hline Tuna Cocok & 28 & 1997,2219 & 71,3293 & \multirow{2}{*}{$\begin{array}{c}\mathrm{Fh}=1,83 \\
\mathrm{Ft}=2,40 \\
\mathrm{Fh}<\mathrm{Ft}\end{array}$} \\
\hline Galat & 2 & 78,1 & 39,05 & \\
\hline
\end{tabular}

Setelah dilakukan analisis, pada uji keberar tian diperoleh nilai $F_{h}$ adalah 9,25. Disisi lain nilai $F_{t}$ adalah 4,17. Syarat uji keberartian adalah $F_{h}>F_{t}$. Dari analisis uji keberartian dapat dinyatakan bahwa koefisien arah regresi tersebut berarti. Untuk uji linea ritas didapatkan nilai $F_{h}$ sebesar 1,83 dan ni lai $F_{t}$ se besar 2,40. Syarat uji linearitas adalah $F_{h}<F_{t}$. Dari hasil uji linearitas dapat dinyatakan data tersebut adalah regresi linear. Dengan demikian, dapat di nyatakan hubungan regresi linear antara kompetensi pengetahuan dengan tugas-tugas dalam buku ajar adalah berarti.

Setelah dilakukan uji regresi linear sederhana dilakukan uji hubungan dua variabel. Uji hubungan dua variabel dilakukan untuk mengetahui besar hu bungan kompetensi pengetahuan dengan tugas-tugas dalam buku ajar IPA terpadu. Dari hasil analisis diperoleh nilai $r$ sebesar 0,48 . Setelah berpedoman dengan tabel interpretasi terhadap koefisien korelasi maka diketahui hubungan antara kompetensi penge tahuan dengan nilai tugas dalam buku ajar IPA ter padu memiliki tingkat hubungan sedang.

Setelah mendapatkan nilai $r$ dari uji hubungan dua variabel peneliti melakukan uji hipotesis. Dari uji hipotesis dapat dinyatakan bahwa terdapat hubungan yang berarti antara kompetensi pengetahuan dengan tugas dalam buku ajar IPA terpadu. Setelah peneliti melakukan uji hipotesis, peneliti melakukan perhi tungan nilai koefisien determinasi. Perhitungan nilai koefisien determinasi dilakukan melihat kontribusi buku ajar IPA terpadu terhadap kompetensi siswa. Berdasarkan hasil koefisien determinasi, didapatkan bahwa buku ajar IPA terpadu berkontribusi terhadap kompetensi pengetahuan siswa sebesar $23,66 \%$.

Hasi penelitian ketiga adalah pengaruh buku ajar IPA terpadu tema kesehatan pencernaan dalam model pembelajaran kontekstual adaptif terhadap kompetensi keterampilan siswa. Data kompetensi keterampilan IPA siswa diperoleh melalui penilaian 
unjuk kerja selama kegiatan diskusi dan eksperimen. Penilaian diambil sebelum menggunakan buku ajar IPA terpadu dan selama menggunakan buku ajar IPA terpadu. Penilaian dilakukan berdasarkan indikator masing-masing aspek yang dinilai sesuai rubrik pens koran kompetensi pengetahuan. Penelitian ini dilaku kan sebanyak empat kali perlakuan akan tetapi untuk eksperimen dilakukan tiga kali perlakuan karena ke terbatasan alat laboratorium. Deskripsi data kom petensi keterampilan IPA siswa dapat dinyatakan pada Tabel 9.

Tabel 9. Deskripsi Data Kompetensi Keterampilan Awal dan Keterampilan Akhir

\begin{tabular}{|l|c|c|c|c|c|c|}
\hline \multicolumn{1}{|c|}{ Keadaan } & $\mathrm{N}$ & $\begin{array}{c}\text { Nilai } \\
\text { Tertinggi }\end{array}$ & $\begin{array}{c}\text { Nilai } \\
\text { Terendah }\end{array}$ & $\bar{X}$ & $\mathbf{S}^{\mathbf{2}}$ & $\mathrm{S}$ \\
\hline $\begin{array}{l}\text { Nilai } \\
\text { Keterampilan } \\
\text { Awal }\end{array}$ & 32 & 87,5 & 40,63 & 60,94 & 205,35 & 14,33 \\
\hline $\begin{array}{l}\text { Nilai } \\
\text { Keterampilan } \\
\text { Akhir }\end{array}$ & 32 & 95,84 & 42,71 & 67,78 & 241,18 & 15,53 \\
\hline
\end{tabular}

Analisis data dimulai dari uji normalitas. Uji normalitas yang digunakan adalah uji Lilliefors. Hasil uji normalitas didapatkan harga $L_{o}$ dan $L_{t}$ pada taraf nyata 0,05 . Hasil uji normalitas didapatkan dapat dinyatakan pada Tabel 10.

Tabel 10. Hasil Uji Normalitas Keterampilan Data Keterampilan Awal dan Akhir

\begin{tabular}{|l|c|c|c|c|c|}
\hline \multicolumn{1}{|c|}{ Penilaian } & $\mathbf{N}$ & $\alpha$ & Lo & Lt & Keterangan \\
\hline $\begin{array}{l}\text { Keterampilan } \\
\text { Awal }\end{array}$ & 32 & 0.05 & 0.113 & 0.156 & Normal \\
\hline $\begin{array}{l}\text { Keterampilan } \\
\text { Akhir }\end{array}$ & 32 & 0.05 & 0.100 & 0.156 & Normal \\
\hline
\end{tabular}

Setelah didapatkan data terdistribusi normal maka dilakukan uji hubungan dua variabel. Peneliti melakukan Uji hubungan dua variabel untuk me ngetahui pengaruh yang berarti pada penggunaan buku ajar IPA terpadu terhadap kompetensi ke terampilan siswa. Dari hasil analisis diperoleh nilai korelasi sebesar 0,98. Setelah dilakukan analisis uji hubungan dua variabel maka nilai korelasi ini kemudian digunakan untuk menguji hipotesis. Hasil analisis uji hipotesis pada kompetensi keterampilan adalah penggunaan buku ajar IPA terpadu tema kesehatan pencernaan dalam model pembelajaran kontekstual adaptif memberikan pengaruh yang ber arti terhadap kompetensi keterampilan siswa kelas VIII SMPN 15 Padang.

\section{Pembahasan}

Hasil penelitian pada kompetensi sikap yaitu penggunaan buku ajar IPA terpadu tema kesehatan pencernaan dalam model pembelajaran kontekstual adaptif memberikan pengaruh yang berarti terhadap kompetensi sikap siswa. Penggunaan buku ajar IPA terdapu dalam model pembelajaran kontekstual adaptif dapat meningkatkan kompetensi sikap karena pada pelaksanaan materi pembelajaran dihubungkan dengan dunia nyata siswa. Pembelajaran IPA yang dilaksanakan perlu dikaitkan dengan penerapan IPA dalam kehidupan sehari-hari, lingkungan, dan tekno logi. Dengan pelaksanaan pembelajaran seperti ini, siswa diharapkan mampu menerapkan kompetensi IPA yang dipelajari di sekolah menjadi perilaku da lam kehidupan masyarakat dan memanfaatkan lingku ngan sebagai sumber belajar ${ }^{[13]}$. Penggunaan materi pembelajaran IPA secara terpadu dapat meningkat kan kompetensi sikap, meliputi: percaya diri, rasa ingin tahu, komunikatif, disiplin, tanggung respon dan kerja keras ${ }^{[8]}$

Hasil uji hipotesis pada kompetensi penge tahuan menunujukkan bahwa penggunaan buku ajar IPA tema kesehatan pencernaan dalam model pem belajaran kontekstual adaptif memberikan pengaruh yang berarti terhadap kompetensi penge tahuan siswa kelas VIII SMPN 15 Padang. Hasil dari uji hubungan dua variabel dapat dinyatakan hubu ngan antara kom petensi pengetahuan dengan nilai tugas pengetahuan dalam buku ajar IPA terpadu memiliki tingkat hu bungan sedang. Buku ajar IPA terpadu tema ke sehatan pencernaan dalam model pembelajaran kon tekstual adaptif dapat meningkat kan kompetensi pengetahuan siswa, karena buku ajar IPA terpadu di kemas secara terpadu dan kontekstual. Pembelajaran kontekstual adalah pembelajaran yang mengaitkan materi pengetahuan dengan kehidupan nyata serta dapat diaplikasikan dalam kehidupan sehari-hari ${ }^{[13]}$. Keterpaduan dalam IPA dapat membantu siswa untuk memperoleh penguatan suatu pemahaman dari fungsi IPA dalam kehidupan sehari-hari dan dunia dimana mereka hidup ${ }^{[9]}$.

Hasil Analisis data kompetensi keterampilan didapatkan bahwa penggunaan buku ajar IPA terpadu tema kesehatan pencernaan dalam model pembe lajaran kontekstual adaptif memberikan pengaruh yang berarti terhadap kompetensi keteram pilan siswa. Penggunaan buku ajar IPA terpadu tema ke sehatan pencernaan dalam model pembelajaran kon tekstual adaptif dapat meningkatkan kompetensi keterampilan siswa. Hal ini disebabkan karena buku ajar IPA terpadu tema kesehatan pencernaan memuat kegiatan-kegiatan kelompok dan pada pembelajaran nya juga digunakan model pembelajaran kontekstual adaptif. Salah satu kelebihan dari model pembelaja ran kontekstual adaptif adalah pada pembelajarannya mendorong proses sains dimana model pembelajaran ini melatih keterampilan sains siswa sehingga siswa terbiasa bekerja dalam proses ilmiah ${ }^{[14]}$.

Berdasarkan hasil analisis data dari ketiga kompetensi yaitu sikap pengetahuan dan keteram pilan dapat dinyatakan bahwa penggunaan buku ajar IPA terpadu tema kesehatan pencernaan dalam model pembelajaran kontekstual adaptif memberikan penga ruh yang berarti terhadap kompetensi siswa kelas VIII SMPN 15 Padang. Buku ajar ini cocok diguna kan oleh guru-guru disekolah untuk menunjang pem belajaran IPA terpadu sehingga dapat meningkatkan kompetensi siswa. Siswa dapat menggunakan buku ajar IPA terpadu ini untuk meningkatkan pemahaman terhadap materi IPA terpadu. 
Penelitian yang dilakukan tidak terlepas dari keterbatasan-keterbatasan yang dihadapi oleh pene liti. Penjelasan tentang keterbatasan yang terjadi sela ma penelitian diharapkan akan menjadi pengalaman dan dapat diperbaiki untuk masa yang akan datang. Adapun keterbatasan-keterbatasan pelaksanaan pem belajaran menggunakan buku ajar IPA terpadu tema kesehatan pencernaan dalam model pembelajaran kontekstual adaptif sebagai berikut:

Keterbatasan pertama adalah materi pelajaran yang diterapkan pada penelitian ini masih terbatas pada satu tema. Penelitian ini hanya dilakukan pada kelas VIII semester satu. Tema yang diterapkan pada penelitian ini adalah tema kesehatan pencernaan. Untuk solusi dari keterbatasan ini diharapkan ada penelitian lanjutan mengenai buku ajar IPA terpadu pada tema lainnya.

Keterbatasan kedua adalah peneliti masih me rasa kesulitan dalam mengelola kelas. Hal ini menye babkan terjadi keributan dan kurang terkontrolnya siswa. Salah satu solusi untuk pengelolaan kelas bisa dilakukan dengan cara meningkatkan ketegasan dan kedisiplinan guru dalam pembelajaran.

Keterbatasan ketiga adalah pada tahap awal siswa kurang terbiasa dengan tugas-tugas yang ada dalam buku ajar. Dalam mengerjakan tugas siswa masih merasa kesulitan dalam mencari jawaban. Hal ini disebabkan oleh kurangnya kebiasaan membaca siswa. Keterbatasan ini dapat diatasi dengan cara membimbing siswa melakukan kebiasaan membaca sebelum pembelajaran dimulai.

\section{KESIMPULAN}

Berdasarkan analisis data dapat dikemukakan kesimpulan dari penelitian ini. Sebagai kesimpulan penelitian adalah penggunaan buku ajar IPA terpadu tema kesehatan pencernaan dalam model pembe lajaran kontekstual adaptif memberikan pengaruh yang berarti terhadap kompetensi siswa kelas VIII mencakup sikap, pengetahuan dan keterampilan di SMPN 15 Padang. Penggunaan buku ajar IPA ter padu tema kesehatan pencernaan dalam model pem belajaran kontekstual adaptif dapat meningkatkan kompetensi siswa.

\section{UCAPAN TERIMA KASIH}

Terima kasih kepada Kemenristek Dikti RI atas Penelitian Produk Terapan 2017, No.Kontrak: 777/UN35/LT/2017. Penelitian ini merupakan bagian atau kombinasi dari penelitian tersebut. Terimakasih kepada semua pihak yang sudah membantu terlak sananya penelitian ini.

\section{DAFTAR PUSTAKA}

[1] Rusman. 2012. Model-Model Pembelajaran (Me ngembangkan Profesionalisme Guru). Jakarta: PT. Raja Grafindo Persada.

[2] Daryanto. 2014. Pendekatan Pembelajaran Saintifik Kurikulum 2013. Yogyakarta: Gava Media.
[3] Depdiknas. 2008. Panduan Pengembangan Ba han Ajar. Jakarta: Direktorat Jendral Mana jemen Pendidikan Dasar dan Menengah.

[4] Mulyasa. 2014. Pengembangan dan imple menttasi kurikulum 2013. Bandung: Remaja Rosdakarya.

[5] Risdalina. 2014. Pembelajaran IPA Terpadu dan Penilaiannya dalam Kurikulum 2013 di Sekolah Menengah Pertama. Proceeding Seminar Nasional IPA V Scientific Learning dalam Konten dan Konteks Kurikulum 2013, 193-201.

[6] Abdul Majid. 2014. Pembelajaran Tematik Terpadu. Bandung: Remaja Rosdakarya.

[7] Trianto. 2012. Model Pembelajaran Terpadu. Jakarta: Bumi Aksara.

[8] Asrizal, Ali Amran, Azwar Ananda, Festiyed, Winda Arma Yana. 2017. Effectiveness of Integrated Science Learning Materials of Waves in Life By Integrating Digital Age Literacy On Grade VIII Students. Proceeding of the $1^{\text {st }}$ Universitas Riau Internasional Con ference on Educational Sciences, Vol.1, No.1, 85-92.

[9] Asrizal, Liza R, Festiyed. 2017. Pengembangan Bahan Ajar IPA Terpadu Gerak Benda dan Makhluk Hidup Bermuatan Literasi Saintifik Untuk Siswa SMP Kelas VIII. Prosiding Semirata 2017 Bidang MIPA BKS-PTN Wilayah Barat Jambi, Buku 2, 1044-1056.

[10] Junaidy Syam, Asrizal, Zulhendri Kamus. 2017. Pengaruh Buku Ajar Bermuatan Kecerdasan Komprehensif dalam Model Pembelajaran Ber basis Masalah terhadap Kompetensi Fisika Pe serta didik Kelas X SMA N 9 Padang. Pillar of Physics Education, Vol.9, 73-80.

[11] Nirnawati. 2015. Pengembangan Buku Ajar Menulis Nonsastra Berdasarkan Strategi Raft (Role Audience Format Topic) Untuk SMP/MTS Kelas VIII. Jurnal Pendidikan Bahasa dan Sastra Indonesia UNY.

[12] Asrizal, Ramadhan Sumarmin. 2017. Pengem bangan Bahan Ajar IPA Terpadu Bermuatan Literasi Era Digital untuk Mengimple mentasikan Kurikulum 2103 Pada Siswa SMP Kelas VIII. FMIPA, Universitas Negeri Padang

[13] M. Hosnan. 2014. Pendekatan saintifik dan kon tekstual dalam pembelajaran abad 21. Badung: Ghalia Indonesia.

[14] Asrizal. 2017. Model Pembelajaran Kontekstual Adaptif. Padang : Universitas Negeri Padang.

[15] Septian Ari Kususa, Sudarti, Pramudya Dwi Arista. 2017. Pengembangan Modul Fisika Berbasis Kontekstual pada Materi Alat-Alat Optik dalam Pembelajaran di Kelas X SMAN 3 Lumajang. Jurnal Pembelajaran Fisika, Vol.6, No.2, 158-165. 